\title{
Dukungan Orang Tua dalam Mengembangkan Motorik Kasar Anak Cerebral Palsy pada Anak Usia Dini
}

\author{
Venita Tri Septiana ${ }^{1}$, Ajeng Ayu Widiastuti $\bowtie$ 2) \\ Pendidikan Guru Pendidikan Anak Usia Dini, Universitas Kristen Satya Wacana Salatiga \\ DOI: $10.31004 /$ obsesi.v4i1.298
}

\begin{abstract}
Abstrak
Tujuan penelitian ini adalah menggali informasi tentang dukungan apa saja yang diberikan orang tua dalam mengembangkan motoric kasar anak cerebral palsy. Penelitian ini menggunakan jenis penelitian studi kasus (case study). Didalam penelitian ini, peneliti memilih subjek penelitian yaitu 3 orang yang memiliki gangguan Cerebral palsy yang masingmasing memiliki usia yang berbeda. Subjek penelitian tersebut adalah seorang anak laki-laki berinisial J berusia 7 tahun, seorang anak perempuan yang berinisial A berusia 7 tahun, dan seorang anak laki-laki yang berinisial $\mathrm{Z}$ berusia 5 tahun. Berdasarkan hasil penelitian ini menyatakan bahwa dukungan yang diberikan orang tua kepada subjek dalam mengembangkan motoric kasar adalah dukungan emosional berupa empati dan perhatian kepada anak dan dukungan instrumental yaitu memberikan bantuan berupa barang, memberi peluang waktu, dll kepada anak.
\end{abstract}

Kata kunci: cerebral palsy; dukungan orang tua; perkembangan motoric kasar

\begin{abstract}
:
The purpose of this study is to explore information about what support is given by parents in developing gross motor skills of cerebral palsy children. This research uses a study in case of research. In this study, researchers chose a research subject that has three people who have Cerebral Palsy of different ages. The subjects of the study were boys with the initial "J", 7 years old, " $Z$ " 5 years old, and a girl with initial " $A$ " 7 years old. Based on the results of this study stated that the support was given by parent to the subject in developing gross motor skills is in the form of emotional support in the form of including empathy and attention to children and instrumental support which is assisting in the form of goods, giving time opportunities, etc to children
\end{abstract}

Keywords: cerebral palsy; parent's support; gross motor development

Copyright (c) 2019 Venita Tri Septiana, Ajeng Ayu Widiastuti

$\triangle$ Corresponding author:

Email Address : venitatriseptiana0809@gmail.com (Salatiga, jawa Tengah)

Received 10 October 2019, Accepted 13 October 2019, Published 31 October 2019

\section{PENDAHULUAN}

Cerebral Palsy atau yang sering disebut $\mathrm{CP}$ merupakan suatu gangguan pada motorik dan postur tubuh seseorang disebabkan oleh adanya gangguan pada otak yang berfungsi untuk mengendalikan motoric (Bigge, 1991)(Nurfadilla, Gamayani, and Dewi Nasution 2018). Cerebral Palsy adalah suatu kondisi yang ditandai oleh adanya kelumpuhan, kelemahan, tidak adanya koordinasi, atau gangguan fungsi motorik lainnya 
disebabkan oleh karena gangguan pada otak yang mengendalikan motoric (Perlstein, 1970) (Maysaroh 2013)

Cerebral palsy adalah suatu gangguan ditandai dengan adanya kesulitan gerak yang sebabkan oleh kelainan pada otak (Bandi Delphie, 2006)(Tifali 2014). Cerebral palsy merupakan kondisi tubuh yang ditandai dengan adanya kekakuan yang disebabkan oleh otak yang mengalami gangguan, sehingga kekakuan tersebut berakibat pada anggota gerak tubuh (Assjari , 1995)(Aisyah 2017).

Cerebral Palsy $(\mathrm{CP})$ merupakan suatu gangguan pada motorik dan postur tubuh yang biasanya terlihat pada masa bayi atau pada anak usia dini. Cerebral Palsy biasanya disebabkan oleh karena mengalami gangguan pada otak yang terjadi pada saat sebelum, selama, atau setelah lahir. (Berker \& YalÇin, 2010)(Sakdiyah 2012). Selanjutnya cerebral palsy adalah suatu bentuk gangguan yang disebabkan oleh adanya gangguan yang terdapat di dalam otak, kelainannya bersifat kekakuan dan kelayuhan (Sujarwanto, 2005)(Afifah 2017). Berdasarkan dari tingkat keparahan Cerebral Palsy terbagi dalam 2 golongan yaitu golongan ringan, dan golongan berat. apabila dilihat dari golongan ringan, memiliki ciri-ciri yaitu memiliki gangguan pada motorik halus seperti membuat tulisan, menggunting sesuatu, keseimbangan pada saat berjalan, tidak dapat mengontrol pergerakan pada saat menulis dan selalu mengeluarkan air liur. sedangkan apabila dilihat dari golongan berat yang memiliki ciri-ciri yaitu tidak dapat menggerakan kakinya (berjalan) sehingga membutuhkan perawatan yang intensif dan berjangka waktu yang panjang(Hermanto 2016).

Motorik kasar merupakan aktivitas yang dilakukan secara fisik dengan menggunakan otot-otot besar, misalnya otot yang terletak di lengan, otot yang terletak di tungkai, otot yang terletak di bahu, otot pinggang dan otot perut. Contoh aktivitas yang menggunakan motoric kasar adalah berjalan, berjinjit, melompat, meloncat, berlari dan berguling (Firmawati, 2011)(Gustiana 2011).

Motorik kasar merupakan suatu aktivitas fisik yang menggunakan otot-otot besar baik menggunakan sebagian atau seluruh anggota tubuh (Fikriyati, 2013)(Hidayanti 2013). Motorik kasar merupakan suatu aktivitas fisik yang menggunakan seluruh otot-otot besar pada tubuh atau menggunakan sebagian besar otot yang ada dalam tubuh maupun seluruh anggota tubuh (Decaprio, 2013)(Pratiwi and Kristanto 2014). keterampilan motorik kasar adalah suatu keterampilan yang melibatkan gerakan otot yang besar, misalnya berjalan, dan menggerakkan lengan (Santrock, 2015)(W.Santrock 2015).

Motorik kasar merupakan suatu kegiatan yang menggunakan otot-otot besar pada tubuhnya yaitu berupa gerak lokomotor, gerak non lokomotor dan gerak manipulative (Samsudin, 2005)(Sudarmanto, Pamungkas, and Putranti 2012). Motoric kasar merupakan suatu keahlian yang memerlukan koordinasi sebagian besar bagian tubuh anak (Sujiono, 2010).

Motoric kasar merupakan suatu kemampuan yang ditandai dengan adanya gerakan yang menggunakan otot-otot besarnya (sumantri, 2005)(Mulyani 2018). Motorik kasar merupakan aktivitas pada tubuh yang melibatkan sebagian besar atau seluruh anggota tubuh yang dipengaruhi oleh tingkat kesiapan anak tersebut (Hasninda, 2014).

Berdasarkan hasil sensus penduduk di Indonesia pada tahun 1990 menyatakan bahwa dari 184 juta jiwa diperkirakan terdapat $3.11 \%$ orang penyandang cacat dari berbagai jenis kelainan dan tingkatan usia (Susilo Supeno, 1992), dan diperkirakan terdapat penyandang gangguan CP di Indonesia sebesar 0,5 \%. (Soeharso, 1982: YPAC 1994)(Saharso 2006). Di Indonesia, belum ada data mengenai tentang jumlah Cerebral Palsy. terdapat 2,46\% dari jumlah penduduk Indonesia yaitu mengalami gangguan atau berkebutuhan khusus, dan terdapat sekitar \pm 2 juta adalah anak. Angka kejadiannya penyandang Cerebral Palsy adalah sekitar 1 - 5 per 1000 anak (KONIKA V Medan, 1981, R. Suhasim dan Titi Sularyo)(david smith 2013). Di Indonesia, menurut hasil Riset Kesehatan Dasar yang dilakukan oleh Kementerian Kesehatan Republik Indonesia pada tahun 2010, hasil persentasi anak-anak berusia 24-59 bulan dengan CP adalah 0,09\% (WHO, 2013). 
Berdasarkan observasi penulis pada salah satu Pusat Terapi Anak Berkebutuhan Khusus di Salatiga dan wawancara dengan salah satu terapis yang ada pada Pusat Terapi Anak Berkebutuhan Khusus tersebut. Penelitian ini dilakukan pada bulan Maret hingga bulan April, pada penelitian ini terdapat 3 anak yang mengalami gangguan yang sama yaitu Cerebral Palsy dan mereka memiliki usia berbeda.

Ada seorang anak yang memiliki inisial $\mathrm{J}$ dia adalah seorang anak laki-laki yang berusia 7 tahun, dia tinggal di Krangkeng RT 6 RW 12 Getasan, Kopeng, Jawa Tengah, dia tinggal bersama dengan ibu, kakek dan tante nya. Dia bersekolah pada salah satu SLB Negeri yang terletak di kota Salatiga dan dia melakukan terapi pada salah satu tempat terapi di Salatiga. anak tersebut melakukan terapi $2 x$ dalam seminggu yaitu hari Rabu dan hari Jum'at. Pada saat anak bersekolah dan melakukan terapi, anak diantar dan dijemput oleh tante atau kakeknya serta ditunggu hingga selesai.

Ada seorang anak yang memiliki inisial A dia adalah seorang anak perempuan yang berusia 7 tahun, dia tinggal di desa Jombor Tuntang, Jawa Tengah, dia tinggal bersama dengan kedua orang tua nya dan dia mempunyai seorang adik laki-laki yang berusia 11 bulan. Anak tersebut melakukan terapi pada salah satu pusat terapi di Salatiga. anak tersebut melakukan terapi $2 x$ dalam seminggu yaitu hari selasa dan hari kamis. Pada saat anak melakukan terapi, anak diantar dan dijemput serta ditunggui oleh ayahnya saja dan kadang bersama ibu dan adiknya.

Ada seorang anak yang memiliki inisial $\mathrm{Z}$ dia adalah seorang anak laki-laki yang berusia 5 tahun, dia tinggal di Klaseman Salatiga, Jawa Tengah. dia tinggal bersama dengan kedua orang tua dan kakeknya. Anak tersebut bersekolah pada salah satu TK yang terletak di dekat rumahnya di Klaseman, Salatiga. Anak tersebut sekarang pindah sekolah di Tingkir, Salatiga dan melakukan terapi pada salah satu tempat terapi di Salatiga. Anak tersebut melakukan terapi $2 x$ dalam seminggu yaitu hari senin dan hari kamis. Pada saat anak bersekolah dan melakukan terapi, anak diantar dan dijemput oleh ibu atau bapaknya

Melihat anak yang berinisial J, anak yang beinisial A dan anak yang berinisial $\mathrm{Z}$ dalam melakukan aktivitas sehari-hari yang dibantu oleh orang tua dan orang-orang yang ada di sekitar anak dalam hal ini menunjukkan bahwa orang tua mempunyai peran penting bagi perkembangan anaknya. Orang tua adalah sosok didalam keluarga yang memiliki peranan yang penting dalam perkembangan anaknya. Dukungan Orang tua merupakan salah satu dari dukungan sosial. dukungan sosial merupakan suatu hubungan yang mempunyai makna yang penting misalnya berupa memberikan bantuan dan dukungan yang bermakna (Leavit, 2006)(Syarifa, Alvie, Dewi Mustami'ah 2011). Dukungan sosial adalah bantuan yang mempunyai berbagai jenis yaitu dukungan emosional, dukungan penilaian dan dukungan informasi serta dukungan instrumental (Weiten, 2005)(Dukungan Sosial bagi Keluarga Anak Berkebutuhan Khusus 2012). Dukungan orang tua mempunyai berbagai macam bentuk-bentuk yaitu berupa uang, barang, dll yang bertujuan untuk menunjang perkembangan anak.

Dukungan orang tua terdapat berbagai jenis yaitu dukungan emosional, informasi, atau materi alat bantu yang diberikan (Hallahan, 2006)(Maulida and Dhania 2012). Dukungan social terdapat 2 jenis yaitu: 1. Dukungan emosional adalah suatu dukungan yaitu berupa menunjukkan rasa empati atau kepedulian dan perhatian terhadap orang yang bersangkutan. 2. Dukungan penghargaan adalah suatu dukungan berupa menunjukkan sikap hormat (penghargaan) positif terhadap seseorang atau perasaan individu dan perbandingan positif seseorang dengan orang lain. 3. Dukungan instrumental adalah bentuk dukungan yaitu berupa memberikan bantuan langsung dalam berbagai macam bentuk yaitu bantuan keuangan atau bantuan lainnya. (4) Dukungan informatif merupakan suatu dukungan yaitu berupa pemberian nasehat, petunjuk-petunjuk, saran-saran (House, 1994)(Arfandi, Susilo, and Widodo 2014). 
Dukungan sosial adalah suatu dukungan yang diberikan oleh orang-orang atau kelompok-kelompok lain yaitu berupasutu kenyamanan, perhatian, penghargaan dan bantuan secara langsung yang dapat dirasakan oleh orang tersebut (Cobb, 1976)(Prayascitta 2010).

Dukungan sosial (social support) adalah dukungan yang diberikan oleh orang-orang yang berada didekat subjek berupa informasi, verbal atau non verbal, dan bantuan secara langsung (Gottlieb, 2006)(Pujawati 2016). Dukungan orang tua yaitu dukungan berupa sikap, tindakan, dan penerimaan orang tua terhadap seseorang. Dukungan yang diberikan orang tua terdapat 4 macam yaitu dukungan informasional, penghargaan, emosional dan instrumental (Friedman ,1998)(Maslihah 2011).

Dukungan orang tua adalah dukungan yang diberikan oleh orang-orang yang berada disekitar seseorang berupa dukungan emosional, informasional dan pendampingan yang bertujuan untuk individu mampu menghadapi semua permasalahan yang terjadi didalam kehidupan sehari-hari (Kail \& Cavanaug, 2000)(Siska, Solfema, and Aini 2018). Dukungan orang tua adalah dukungan yang diberikan orang tua yaitu berupa memberikan kesempatan untuk anak yang bertujuan untuk anak dapat mengembangkan kemampuan yang dimilikinya, belajar menjadi seorang yang inisiatif, mengambil keputusan sendiri untuk yang ingin dilakukan dan belajar bertanggung jawab dengan semua keputusan yang diambil (Santrock, 2003).

Melihat pentingnya dukungan orang tua dalam perkembangan motorik kasar pada anak Cerebral Palsy dalam hal ini penulis tertarik untuk mencari tau, menggali informasi lebih lanjut bagaimana dukungan orang tua terdahap perkembangan motorik kasar anak Cerebral Palsy usia 5-7 tahun

\section{METODOLOGI}

Penelitian ini menggunakan jenis penelitian studi kasus (case study). Didalam penelitian ini terdapat 3 anak yang mengalami gangguan Cerebral Palsy dengan usia yang berbeda-beda yaitu anak yang memiliki inisial J adalah seorang anak laki-laki yang berusia 7 tahun, anak yang memiliki inisial A adalah seorang anak perempuan yang berusia 7 tahun dan anak yang memiliki inisial $\mathrm{Z}$ adalah seorang anak laki-laki yang berusia 5 tahun dan tinggal di Kota Salatiga. Penelitian ini menggunakan metode pengumpulan data yaitu wawancara dan observasi. Wawancara pada penelitian ini dilakukan dengan orang tua subjek dan orang-orang yang berada didekat subjek sedangkan observasi yang dilakukan penulis pada penelitian ini adalah dilakukan pada rumah subjek tersebut. Analisis data yang digunakan dalam penelitian ini yaitu analisis secara induktif. Analisis ini adalah membuat suatu abstraksi atau penyimpulan yang mengacu pada bagian-bagian yang telah dikumpulkan setelah itu data dilakukan sistem pengelompokan. Jadi dapat disimpulkan bahwa dalam melakukan penyusunan teori tersebut menggunakan system dari bawah ke atas artinya hasil yang telah didapatkannya tersebut lalu dilakukannya system pengelompokkan sehingga antara satu dengan yang lain mempunyai satu kesatuan yang saling berhubungan.

Langkah-langkah dalam melakukan penelitian ini yaitu

1. Menentukan subjek penelitian yang akan diteliti.

2. Menentukan topik yang akan diteliti.

3. Melakukan wawancara dengan pihak terapis subjek penelitian

4. Melakukan observasi dan wawancara dengan pihak orang tua dan orang yang berada didekat subjek yang dilakukan dirumah subjek

5. Melakukan analisis data 


\section{HASIL DAN PEMBAHASAN}

\section{Dukungan Orang Tua Terhadap Subjek Penelitian Berinisial J}

Dukungan orang tua terlihat jelas kepada subjek tersebut yaitu berupa dukungan emosional dan dukungan instrumental. Pada saat penulis melakukan observasi di rumah subjek, orang tua membantu aktivitas sehari-hari subjek yaitu memandikan subjek, menyendokkan makan untuk subjek, mengajak bermain subjek, pada saat subjek menangis orang tua memenuhi apa saja yang dibutuhkan dan diinginkan, dan pada saat ibu atau tante subjek tersebut pergi, ibu atau tante subjek tersebut meminta kakek atau keluarga lainnya untuk menjaga subjek tersebut agar menghindari hal- hal yang buruk terhadap subjek tersebut. Berdasarkan dari hasil observasi tersebut orang tua memberikan dukungan emosional kepada subjek.

Pada saat penulis melakukan wawancara kepada ibu dan tante subjek tersebut, menurut keterangan dari ibu dan tante subjek tersebut setiap hari tante atau kakek subjek tersebut mengantarkan dan menjemput ke sekolah subjek tersebut serta tante atau kakek tersebut menunggu hingga selesai sekolah. Selain itu, tante atau kakek subjek tersebut mengantarkan dan menjemput subjek pada saat subjek melakukan terapi serta menunggu subjek hingga selesai melakukan proses terapi. Berdasarkan dari hasil wawancara tersebut orang tua memberikan dukungan instrumental atau dukungan bantuan langsung

Pada saat penulis melakukan wawancara kepada salah satu terapis subjek tersebut, menurut keterangan dari salah satu terapis bahwa perkembangan motoric kasar anak pada awalnya yaitu anak dapat berjalan dengan cara berpegangan dengan orang lain tetapi pada saat berjalan anak memiliki keseimbangan yang tidak stabil. Setelah anak melakukan terapi anak tersebut dapat berjalan dengan cara berpegangan dengan orang lain dan pada saat berjalan anak memiliki keseimbangan yang baik.

\section{Dukungan Orang Tua Terhadap Subjek Penelitian Berinisial A}

Dukungan orang tua terlihat jelas kepada subjek tersebut yaitu berupa dukungan emosional dan dukungan instrumental. Pada saat penulis melakukan observasi di rumah subjek, orang tua membantu aktivitas sehari-hari subjek yaitu memandikan subjek, menyendokkan makan untuk subjek, mengajak bermain subjek, pada saat subjek menangis orang tua memenuhi apa saja yang dibutuhkan dan diinginkan, dan pada saat ibu subjek pergi, ayah subjek tersebut yang berada dirumah supaya subjek ada yang menjaga atau sebaliknya apabilanya ayahnya yang pergi maka ibunya yang berada dirumah untuk menjaga dan apabila kedua orang tua subjek maka orang tua tersebut mengajak subjek dan adiknya untuk pergi bersama. Berdasarkan dari hasil observasi tersebut orang tua memberikan dukungan emosional kepada subjek.

Pada saat penulis melakukan wawancara kepada ibu dan ayah subjek tersebut, menurut pengakuan dari ibu dan ayah subjek bahwa setiap hari mengantarkan dan menjemput subjek pada saat subjek melakukan terapi serta menunggu subjek hingga selesai melakukan proses terapi. Selain itu menurut pengakuan dari ibu dan ayah subjek bahwa ibu memberikan sepatu AFO dan Splint dengan cara memesankan sepatu AFO dan Splint tersebut pada ahli yang membuat sepatu AFO dan Splint. Berdasarkan dari hasil wawancara tersebut orang tua memberikan dukungan instrumental atau dukungan bantuan langsung. Pada saat penulis melakukan wawancara kepada salah satu terapis subjek tersebut, menurut keterangan dari salah satu terapis bahwa perkembangan motoric kasar anak pada awalnya yaitu anak belum bisa duduk dalam posisi tegak dan dalam waktu yang singkat. Setelah anak tersebut melakukan terapi anak dapat duduk dalam posisi yang tegak dan dalam waktu yang lama.

\section{Dukungan Orang Tua Terhadap Subjek Penelitian Berinisial Z}

Dukungan orang tua terlihat jelas kepada subjek tersebut yaitu berupa dukungan emosional dan dukungan instrumental. Pada saat penulis melakukan observasi di rumah 
subjek, orang tua membantu aktivitas sehari-hari subjek yaitu memandikan subjek, menyendokkan makan untuk subjek, mengajak bermain subjek, mengawasi anak pada saat bermain dengan tetangganya, dan pada saat subjek menangis orang tua memenuhi apa saja yang dibutuhkan dan diinginkan. dan pada saat ibu subjek pergi, bapak subjek tersebut yang berada dirumah supaya subjek ada yang menjaga atau sebaliknya apabilanya ayahnya yang pergi maka ibunya yang berada dirumah untuk menjaga dan apabila kedua orang tua subjek maka orang tua tersebut mengajak subjek dan adiknya untuk pergi bersama. Berdasarkan dari hasil observasi tersebut orang tua memberikan dukungan emosional kepada subjek.

Pada saat penulis melakukan wawancara kepada ibu dan bapak subjek tersebut, menurut pengakuan ibu dan bapak subjek tersebut setiap hari ibu dan bapak subjek tersebut mengantarkan dan menjemput ke sekolah subjek tersebut. Selain itu, ibu dan bapak subjek tersebut mengantarkan dan menjemput subjek pada saat subjek melakukan terapi serta menunggu subjek hingga selesai melakukan proses terapi. menurut pengakuan dari ibu dan bapak subjek bahwa ibu mendapatkan bantuan berupa sepatu AFO dengan syarat orang tua membawa subjek ke salah satu Rumah Sakit yang berada di kota Semarang untuk diukur kaki subjek yang bertujuan untuk membuat sepatu AFO. Berdasarkan dari hasil wawancara tersebut orang tua memberikan dukungan instrumental atau dukungan bantuan langsung.

Pada saat penulis melakukan wawancara kepada salah satu terapis subjek tersebut, menurut keterangan dari salah satu terapis bahwa Perkembangan motoric kasar anak pada awalnya yaitu anak belum bisa berjalan. Setelah anak tersebut melakukan terapi anak dapat berjalan tetapi pada salah satu kakinya berjalan dengan posisi jinjit.

\section{PEMBAHASAN}

Berdasarkan dari hasil triangulasi data dari penulis bahwa dukungan orang tua dan orang-orang disekitarnya sangat dibutuhkan oleh subjek. Orang tua adalah sosok didalam keluarga yang memiliki peranan yang penting dalam suatu perkembangan anaknya. Dukungan Orang tua merupakan salah satu contoh dari dukungan sosial. Dukungan sosial merupakan suatu hubungan yang mempunyai makna yang penting misalnya berupa memberikan bantuan dan dukungan yang bermakna (Leavit, 2006)

Dukungan orang tua memiliki berbagai jenis yaitu dukungan emosional, dukungan informasi, dukungan instrumental dan dukungan penilaian atau penghargaan. berdasarkan hasil penelitian yang telah dijabarkan bahwa terdapat 2 dukungan yang diberikan oleh orang tuanya, yaitu dukungan emosional dan dukungan instrumental (bantuan langsung) (Sarafino, 1994), (Johnson, 2006), (Clarke, 2001), dan (House, 2004)..

Dukungan emosional adalah suatu dukungan berupa memberikan suatu kelekatan, kehangatan, kepedulian, dan ungkapan empati yang bertujuan untuk membuat seseorang yang bersangkutan memiliki perasaan yang dicintai dan diperhatikan. Penelitian ini didukung oleh hasil observasi penulis terhadap ketiga subjek yaitu pada saat orang tua subjek membantu aktivitas sehari-hari subjek (Johnson, 2006). Berdasarkan hasil observasi ketiga subjek tersebut orang tua memberikan suatu kelekatan, kehangatan, kepedulian, dan ungkapan empati yang bertujuan untuk seseorang yang bersangkutan memiliki perasaan yang dicintai dan diperhatikan.

Dukungan bantuan langsung adalah bantuan ini dapat berupa bantuan instrumental yaitu berupa memberikan suatu barang, pelayanan, dukungan keuangan, menyediakan peralatan, dan memberikan bantuan dalam melakukan berbagai aktivitas, serta memberikan waktu untuk seseorang yang bersangkutan. (Johnson, 2006). Penelitian ini didukung oleh hasil wawancara penulis terhadap orang tua dan orang terdekat ketiga subjek yaitu pada saat orang tua subjek mengantar, menjemput ke sekolah dan menunggu hingga selesai kegiatan sekolah, serta orang tua mengantar, menjemput ke tempat terapi dan menunggu hingga selesai kegiatan terapi. Selain itu terdapat orang tua memberikan alat bantu untuk motoric kasar yaitu berupa sepatu AFO dan Splint dan terdapat orang tua memberikan alat 
bantu untuk motoric kasar yaitu berupa hanya sepatu AFO saja. Berdasarkan hasil wawancara dengan orang tua dan orang disekitar ketiga subjek tersebut bahwa orang tua memberikan suatu barang yaitu berupa sepatu AFO dan Splint, pelayanan, dukungan keuangan, memberi peluang waktu.

Berdasarkan hasil dari wawancara dengan salah satu terapis dari ketiga subjek tersebut bahwa ketiga subjek tersebut mengalami perkembangan pada motoric kasar anak. Dalam hal ini dukungan yang orang tua berikan kepada subjek ternyata tidak sia-sia dalam hal ini dibuktikan bahwa ketiga subjek tersebut mengalami perkembangan pada motorik kasarnya.

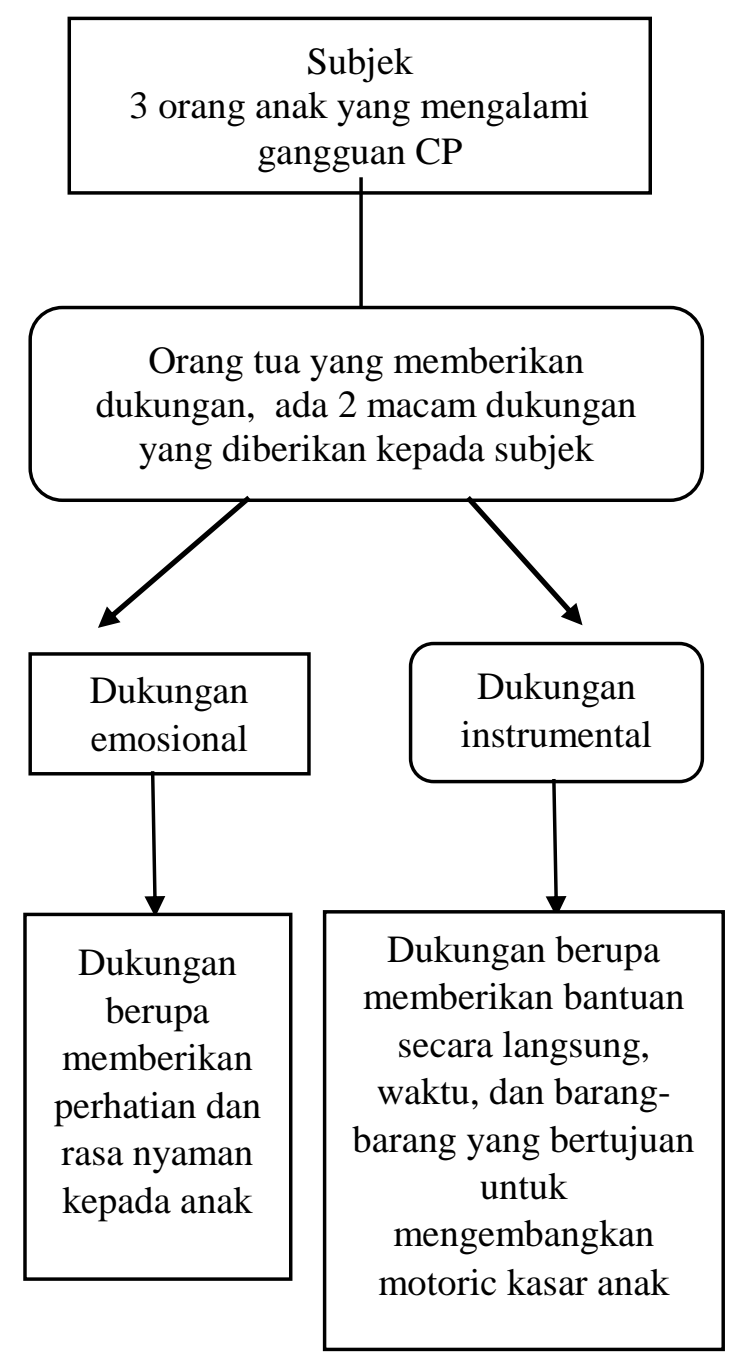

Gambar 1 Hasil Penelitian

\section{SIMPULAN}

Dalam penelitian ini 3 orang subjek yang mengalami Cerebral Palsy yang memiliki usia yang berbeda. Subjek tersebut adalah seorang anak laki-laki berinisial J berusia 7 tahun, seorang anak perempuan berinisial A berusia 7 tahun dan seorang anak laki-laki berinisial $\mathrm{Z}$ berusia 5 tahun. Subjek tersebut mendapatkan dukungan dari orang tua dan orang yang berada didekatnya. Dukungan yang diberikan adalah dukungan emosional dan dukungan instrumental.

\section{UCAPAN TERIMAKASIH}

Terimakasih kepada orang tua dan keluarga dari ketiga subjek penelitian saya yang sudah memberikan ijin untuk melakukan observasi dirumah dan melakukan wawancara, 
dan terima kasih kepada terapis dari ketiga subjek penelitian yang sudah memberikan ijin untuk melakukan wawancara serta kepada pengelola Jurnal Obsesi yang berkenan menerbitkan hasil penelitian penulis yang sederhana ini.

\section{DAFTAR PUSTAKA}

Afifah, Hanum Zulfa. 2017. "Peningkatan Kemampuan Membaca Permulaan Dengan Menggunakan Media Buku Pop-Up Pada Anak Cerebral Palsy Kelas IV SLB G Daya Ananda Kalasan." Jurnal Widia Ortodidaktika 6(8).

Aisyah, Sarah Andriani. 2017. "Penanganan Anak Cerebral Palsy Melalui Permainan Bowling Di Paud Inklusi Saymara Kartasura Tahun Ajran 2016/2017."

Arfandi, Zemmy, Eko Susilo, and Gipta Galih Widodo. 2014. “Hubungan Antara Dukungan Sosial Keluarga Dengan Kemampuan Perawatan Diri Pada Anak Retardasi Mental Di Slb Negeri Ungaran." Jurnal Mahasiswa Program Studi Ilmu Keperawatan Stikes Ngudi 26: $1-6$.

david smith, J. 2013. Sekolah Inklusif Konsep Dan Penerapan PembelajaranNo Title.

"Dukungan Sosial Bagi Keluarga Anak Berkebutuhan Khusus." 2012. Jurnal Insan Media Psikologi 13(1): 12-20.

Gustiana, Asep Deni. 2011. "Pengaruh Permainan Modifikasi Terhadap Kemampuan Motorik Kasar Dan Kognitif Anak Usia Dini (Studi Kuasi Eksperimen Pada Kelompok B TK Kartika Dan TK Lab. UPI)." Jurnal Penelitian Pendidikan (2): 191-200.

Hermanto, SP. 2016. “Modifikasi Model Pembelajaran Bagi Anak Cerebral Palsy (Suatu Tantangan Kreativitas Guru)." Majalah Ilmiah Pembelajaran 2(2): 185-95.

Hidayanti, Maria. 2013. "Peningkatan Kemampuan Motorik Kasar Anak Melalui Permainan Bakiak Maria." Pendiidkan Anak Usia Dini 7: 195-200.

Maslihah, Sri. 2011. "Studi Tentang Hubungan Dukungan Sosial, Penyesuaian Sosial Di Lingkungan Sekolah Dan Prestasi Akademik Siswa Smpit Assyfa Boarding School Subang Jawa Barat." Jurnal Psikologi Undip 10(2): 103-14.

Maulida, Siti Rochmah, and Dhini Rama Dhania. 2012. "Hubungan Antara Kepercayaan Diri Dan Dukungan Orang Tua Dengan Motivasi Berwirausaha Pada Siswa SMK." Jurnal Psikologi Undip 11(2): 1-8.

Maysaroh, A. 2013. "Asuhan Keperawatan Pada Anak Dengan Cerebral Palsy."

Mulyani, Wiwit. 2018. "Peran Aktivitas Bermain Ular-Naga Terhadap Perkembangan Motorik Kasar Di Taman Kanak-Kanak Melati Rejosari Mataram Lampung Tengah."

Nurfadilla, Hazna Nadya, Uni Gamayani, and Gita Tiara Dewi Nasution. 2018. "Komorbiditas Pada Penyandang Cerebral Palsy (CP) Di Sekolah Luar Biasa (SLB)." Dharmakarya: Jurnal Aplikasi Ipteks untuk Masyarakat 7(2): 90-96. http://jurnal.unpad.ac.id/dharmakarya/article/view/19403.

Pratiwi, Yhana, and M. Kristanto. 2014. “Upaya Meningkatkan Kemampuan Motorik Kasar (Keseimbangan Tubuh) Anak Melalui Permainan Tradisional Engklek Di Kelompok B Tunas Rimba II Tahun Ajaran 2014/2015." Jurnal Penelitian PAUDIA 3(2): 18-39.

Prayascitta, Putri. 2010. "Huubungan Antara Coping Stress Dan Dukungan Sosial Dengan Motivasi Belajar Remaja Yang Orang Tuanya Bercerai."

Pujawati, Zulva. 2016. "Hubungan Kontrol Diri Dan Dukungan Orang Tua Dan Perilaku Disiplin Pada Santri Di Pondok Pesantren Darussa'adah Samarindaa." eJournal Psikologi 4(2): 227-36.

Saharso, D. 2006. “Cerebral Palsy: Diagnosis Dan Tata Laksana." Continuing Education Ilmu Kesehatan Anak XXXVI Kapita Selekta Ilmu Kesehatan Anak VI: 30-31.

Sakdiyah, Hallmatus. 2012. "Penerimaan Orang Tua Yang Memiliki Anak Penyandang Cerebral Palsy (Sebuah Studi Kasus)."

Siska, Marina, Solfema Solfema, and Wirdaul Aini. 2018. "Hubungan Dukungan Sosial Orang Tua Dengan Hasil Belajar Santri Di MDA Nurul Haq Nagari Cubadak Kecamatan Dua Koto Kabupaten Pasaman." Spektrum: Jurnal Pendidikan Luar Sekolah 
(PLS) 1(2): 238.

Sudarmanto, S, Joko Pamungkas, and Febrita Cipta Putranti. 2012. "Peningkatan Kemampuan Motorik Kasar Melalui Tari Aswa Tamtama Pada Kelompok B Di TK ABA Wirobrajan I." Jurnal Pendidikan Anak 1(2).

Syarifa, Alvie, Dewi Mustami'ah, and Wiwik Sulistiani. 2011. "Hubungan Antara Dukungan Sosial Orang Tua Dengan Komitmen Terhadap Tugas (Task Commitment) Pada Siswa Akselerasi Tingkat SMA." Jurnal Insan Media Psikologi 13(1): 1-11.

Tifali, Merisya Gabrina. 2014. "Meningkatkan Kemampuan Motorik Halus Melalui Media Papan Alur Pada Anak Cerebral Palsy Tipe Spastik." E-JUPEKhu (Jurnal Ilmiah Pendidikan Khusus) 3(September): 455-66.

W.Santrock, John. 2015. Perkembangan Anak. ed. Wibi Hardani. 